\title{
Ecological Plasticity of New Winter Wheat Varieties Under Environments of Ukrainian Forest-Steppe and Polissia
}

\author{
Oleksandr Demydov, Vira Kyrylenko, Bohdana Blyzniuk*, Halyna Volohdina, \\ Oleksandr Humeniuk, Inna Misiura, Iryna Pravdziva
}

Department of Cereal Crops Breeding, The V. M. Remeslo Myronivka Institute of Wheat of the NAAS, National Academy of Agrarian Sciences of Ukraine, Tsentralne Village, Ukraine

\author{
Email address: \\ kolomyets359@gmail.com (B. Blyzniuk) \\ ${ }^{*}$ Corresponding author
}

\section{To cite this article:}

Oleksandr Demydov, Vira Kyrylenko, Bohdana Blyzniuk, Halyna Volohdina, Oleksandr Humeniuk, Inna Misiura, Iryna Pravdziva. Ecological Plasticity of New Winter Wheat Varieties Under Environments of Ukrainian Forest-Steppe and Polissia. American Journal of Agriculture and Forestry. Vol. 9, No. 2, 2021, pp. 53-60. doi: 10.11648/j.ajaf.20210902.12

Received: February 22, 2021; Accepted: March 11, 2021; Published: March 17, 2021

\begin{abstract}
The research was conducted to evaluate winter wheat varieties in terms of yield, stability and plasticity in different agro-ecological zones. Ten varieties of winter wheat were sown during 2015-16-2017-18 in two agro-ecological research zones: Forest-Steppe (the V. M. Remeslo Myronivka Institute of Wheat) and Polissia (Nosivka Plant Breeding and Experimental Station). Methods of descriptive statistics and analysis of variance were used for data statistical processing. For all three years during active plant vegetation the hydrothermal coefficient was $0.9-1.2$ in the Forest-Steppe zone and in the Polissia zone it was 1.0-1.3. Winter wheat yield formation was negatively affected by the conditions of 2016-17 in the ForestSteppe zone and 2017-18 in Polissia zone according to the relative environmental index (REI = 66 and 73, respectively). The analysis of hydrothermal conditions of different agro-climatic zones of winter wheat cultivation indicates on significant variation of the influence of these conditions on individual stages of plant development. This made it possible to identify varieties with high ecological plasticity which are able to respond less to fluctuations in environmental conditions. Using analysis of variance, it was found that winter wheat yielding capacity was significantly influenced by the factors "Zone" and "Year" $(28.8,22.9 \%$, respectively), but they most $(36.4 \%)$ it was influenced by the interaction "Year $\times$ Zone", this indicates a significant difference in the impact of hydrothermal conditions on this trait depending on the agro-ecological zone of cultivation. It was established that the conditions of the Forest-Steppe zone were favorable for the maximum realization of yield potential of the variety Horlytsia myronivs'ka $(8.35 \mathrm{t} / \mathrm{ha}$ ), while the conditions of Polissia zone were favorable for the varieties MIP Dniprianka, MIP Valensiia, Hospodynia myronivs'ka, Estafeta myronivs'ka, Hratsiia myronivs'ka (9.42; 9.65; $9.62 ; 9.69 ; 9.66 \mathrm{t} / \mathrm{ha}$, respectively). According to the regression coefficient, the varieties Trudivnytsia myronivs'ka, Horlytsia myronivs'ka, MIP Valensiia, MIP Kniazhna, Estafeta myronivs'ka ( $b i=0.89 ; 0.89 ; 0.93 ; 0.95 ; 0.99$, respectively) with the best adaptive ability to unvavourable growing conditions were identified. According to the stability variance of the trait, there were identified the most stable varieties, namely MIP Kniazhna, Trudivnytsia myronivs'ka, MIP Dniprianka, Vezha myronivs'ka, Hratsiia myronivs'ka $\left(S^{2} d_{i}=0.07 ; 0.09 ; 0.12 ; 0.17 ; 0.20\right.$, respectively) and the most unstable ones - Horlytsia myronivs'ka, Estafeta myronivs'ka, MIP Valensiia $\left(S^{2} d_{i}=1.33 ; 0.83 ; 0.68\right.$, respectively).
\end{abstract}

Keywords: Ecological Plasticity and Stability, Agro-ecological Zone, Winter Wheat Variety, Yield

\section{Introduction}

To provide the population with crop products based on its biologization through the formation of sustainable highly productive agrobiocenoses is one of the most important tasks of agriculture in Ukraine [2, 20]. The productivity of the agrobiocenosis depends on the successful combination of cultivar and the part of natural living components remaining from the primary ecosystem [20]. Consideration of genotypeenvironment interaction (Genotype - Environment Interaction - GEI) in an important factor when studying new winter wheat 
varieties in different agro-ecological points [6, 10, 24, 27]. The method of Eberhart and Russell [5] which allows determining the size of edaphoclimatic habitats of plant varieties by a relatively simple algorithm has been widely used in crop variety testing. This method is also used to assess the ecological stability and plasticity of valuable economic characteristics and properties of climatypes [9]. The term stability refers to ability of varieties to form a certain level of productivity or other valuable economic characteristics or properties, regardless of environmental conditions [3, 17]. The phenotypic level of trait manifestation is the result of multiple interactions between genetic system of plant organism and conditions of the environment under study $[4,7,15]$. Genotypes that provide a relatively stable level of phenotypic manifestation of traits in different environments are characterized by adaptation on a wider basis. Forms exceeding the rest only in certain environments are specifically adapted. In other words, specific adaptation is closely interacts with the phenomenon of Genotype - Environment Interaction [11, 22, 25]. However, in our opinion, the plasticity of the genotype corresponds to a broad responsiveness, and stability, on the contrary does to narrow. It is also necessary to agree with the opinion of the researchers [18] that plasticity (stability, responsiveness) is not a general characteristic of the genotype, but relates to a specific trait or a set of traits $[1,8,12]$.

The objective of the current study was to estimate winter wheat varieties for their stability and plasticity in terms of yielding capacity in Ukrainian Forest-Steppe and Polissia and to reveal the influence of hydrothermal conditions in these agro-ecological zones on winter wheat yield formation.

\section{Materials and Methods}

The research was conducted during 2015-16-2017-18 in two agro-ecological zones: 1. the V. M. Remeslo Myronivka Institute of Wheat of NAAS of Ukraine (MIW), agroecological zone Forest-Steppe (FS), subzone Dnipro Upland, Northern-Central-Right Bank-Dnipro agroecological region; 2. Nosivka Plant Breeding and Experimental Station of MIW (NPBES) agroecological zone Polissia, Desna agroecological region [13]. Characteristics of these locations are given in table 1 .

Table 1. Short description of environmental conditions of the research.

\begin{tabular}{|c|c|c|c|c|c|c|c|c|c|}
\hline \multirow[b]{2}{*}{ Location } & \multirow[b]{2}{*}{ Zone } & \multicolumn{2}{|c|}{ Coordinates } & \multirow[b]{2}{*}{ Soil type } & \multicolumn{5}{|c|}{ Content in the arable layer of soil } \\
\hline & & Latitude & Longitude & & $\begin{array}{l}\text { Humus, } \\
\%\end{array}$ & $\begin{array}{l}\text { Easily hydrolyzed } \\
\text { nitrogen, \% }\end{array}$ & $\begin{array}{l}\text { Mobile } \\
\text { phosphorus, \% }\end{array}$ & $\begin{array}{l}\text { Exchangeable } \\
\text { potassium, \% }\end{array}$ & $\begin{array}{l}\text { Hydrolytic } \\
\text { acidity }\end{array}$ \\
\hline MIW & Forest-Steppe & $48^{\circ} 56^{\prime} \mathrm{N}$ & $32^{\circ} 32^{\prime} \mathrm{E}$ & $\begin{array}{l}\text { deep, little humus, slightly } \\
\text { leached chornozem }\end{array}$ & 3.8 & 5.9 & 22.1 & 9.6 & 5.8 \\
\hline NPBES & Polissia & $50^{\circ} 93^{\prime} \mathrm{N}$ & $31^{\circ} 69^{\prime} \mathrm{E}$ & $\begin{array}{l}\text { modal, little humus, } \\
\text { leached chornozem }\end{array}$ & 2.6 & 8.5 & 12.2 & 7.5 & 4.6 \\
\hline
\end{tabular}

In order to characterize the weather conditions for rainfed environments the Selyaninov's hydrothermal coefficient (HTC) was used which was calculated by the ratio of total precipitation (in $\mathrm{mm}$ ) for the period with average daily air temperatures above $10^{\circ} \mathrm{C}$ to the total temperature for the same period divided by 10 . According to the HTC values, the comfort of growing season conditions for the growth and development of winter wheat plants was determined: 0.4-0.7 as very arid; $0.8-1.0$ as arid; $1.1-1.3$ as slightly arid; 1.4-1.6 as optimal; $>1.6$ as waterlodgged [19].

To characterize the influence of environmental conditions on yield formation, namely the formation of a certain level of Triticum aestivum L. grain yield and linear parameters of yield formation (plant height), there was used the indicator "relative environmental index" (REI) representing the difference between average yield of all varieties studied for the particular growing season and their average yield for the entire period in percentage $[23,26]$. The calculations were performed according to the formula:

$$
\mathrm{REI}=100 \%+[(\mathrm{Pr}-\mathrm{Psr}) / \mathrm{Psr}] \times 100 \%,
$$

Pr is biometric indicator of the average value of particular trait of all varieties of particular year of the study;

Psr is the average trait of all varieties for the entire period of the study.

The optimum value is $100 \%$. A lower value reflects the negative impact of environmental conditions on yield formation, and a higher value reflects the favorable impact.

To characterize the environment on the basis of relative indicators of HTC (RHTC) and REI it was used the scale: if values of yield formation range from 83 to $117 \%$ (favorable conditions on HTC) the environmental conditions are close to normal; for less than $83 \%$ they are significantly low; for over $117 \%$ they are significantly high. For RHTC indicators in the range of $58-83 \%$ and $117-133 \%$, growing season conditions are considered moderately unfavorable, and for lower than $58 \%$ and higher than $133 \%$ are considered unsatisfactory [23].

Evaluation by the method of Eberhart and Russell $[5,16]$ was performed in two stages. First, wiht analysis of variance it was established level of reliability of the Genotype $x$ Environment interaction for all the varieties studied. Year (cropping season) of the research and location (agroecological zone) were the factors as environment.

The second stage was the assessment of ecological plasticity and stability for each variety. The average yield (Yx) was calculated by the formula:

$$
\mathrm{Y}_{\mathrm{x}}=\sum_{\mathrm{ij}} \mathrm{Y}_{\mathrm{ij}} / \mathrm{v} \times \mathrm{n},
$$

where $\sum_{\mathrm{ij}} \mathrm{Y}_{\mathrm{ij}}$ is the sum of yields for the varieties and the years;

$v$ is the number of varieties;

$n$ is the number of years.

The regression coefficient $\left(b_{i}\right)$ characterizes the average response of the variety to changes in environmental 
conditions, indicates its plasticity and predicts the change of the trait studied within the conditions in which the study is conducted. [5]:

The regression coefficient was calculated by the formula

$$
\mathrm{b}_{\mathrm{i}}=\sum_{\mathrm{j}} \mathrm{Y}_{\mathrm{ij}} \times \mathrm{Ij} / \sum_{\mathrm{j}} \mathrm{I}_{\mathrm{j}}^{2} \text {, }
$$

where $\sum_{\mathrm{j}} \mathrm{Y}_{\mathrm{ij}}$ is the sum yield of the $\mathrm{i}$-th variety in the $\mathrm{j}$-th year,

$\mathrm{Ij}$ is the value of environmental index;

$\sum_{\mathrm{j}} \mathrm{I}_{\mathrm{j}}{ }_{\mathrm{j}}$ is the sum of squares of the environmental index.

It is a positive value, but may be a negative one, e.g. for reduced yields when lodging or disease damage.

As a criterium for assessing the environment it was taken the indicator Ij (environmental index, or productivity of the environmental conditions) that is the deviation of the average value of the trait "Yield" of all varieties in a particular environment from the average in the experiment.

$$
\mathrm{I}_{\mathrm{j}}=\left[\left(\sum_{\mathrm{i}} \sum_{\mathrm{j}} \mathrm{Y}_{\mathrm{ij}} / \mathrm{v}\right)-\left(\sum_{\mathrm{i}} \sum_{\mathrm{j}} \mathrm{Y}_{\mathrm{ij}} / \mathrm{v} \times \mathrm{n}\right)\right],
$$

where $\sum \mathrm{Y}_{\mathrm{ij}}$ is the sum of yield values of all varieties in the ith year;

$\sum_{\mathrm{i}} \sum_{\mathrm{j}} \mathrm{Y}_{\mathrm{ij}}$ is the sum of yield values of all varieties for all years;

$\mathrm{v}$ is number of varieties;

$n$ is the number of years.

Variation in actual yield relative to regression line is determined by the standard deviation from the regression line $\left(\mathrm{S}^{2} \mathrm{~d}_{\mathrm{i}}\right)[5]$ :

$$
\mathrm{S}^{2} \mathrm{~d}_{\mathrm{i}}=[1 /(\mathrm{j}-2)] \times\left[\sum_{\mathrm{j}}\left(\mathrm{Y}_{\mathrm{ij}}-\mathrm{Y}_{\mathrm{i}}\right)^{2}-\mathrm{b}_{\mathrm{i}}^{2} \sum_{\mathrm{j}}\left(\mathrm{Y}_{\mathrm{j}}-\mathrm{Y}_{\mathrm{H}} .\right)^{2}\right]
$$

The model, $\mathrm{Y}_{\mathrm{ij}}=\mu_{1}+\beta_{1} \mathrm{I}_{\mathrm{j}}+\delta_{\mathrm{ij}}$, defines stability parameters that may be used to describe the performance of a variety over a series of environments. $\mathrm{Y}_{\mathrm{ij}}$ is the variety mean of the $i^{\text {th }}$ variety at the $j_{\text {th }}$ environment, $\mu_{1}$ is the $i^{\text {th }}$ variety mean over all environments, $\beta_{1}$ is the regression coefficient that measures the response of the $i^{\text {th }}$ variety to varying environments, $\delta_{\mathrm{ij}}$ is the deviation from regression of the $i^{\text {th }}$ variety at the $j^{\text {th }}$ environment, and $\mathrm{I}_{\mathrm{j}}$ is the environmental index.

The trait (yield) stability variance $\left(\mathrm{S}^{2} \mathrm{~d}_{\mathrm{i}}\right)$ indicates how reliably the variety corresponds to the plasticity by the regression coefficient $b_{i}$. It is established that the increase in variety yield stability is accompanied by a decrease in its plasticity $\left(\mathrm{S}^{2} \mathrm{~d}_{\mathrm{i}}\right)$.

\section{Results and Discussion}

\subsection{Agro-ecological Conditions of the Forest-Steppe and Polissia Zones}

The average long-term (ALT) air temperature in the Forest-Steppe zone was $8.3^{\circ} \mathrm{C}$, but for some years significant deviations were observed from $6.0^{\circ} \mathrm{C}$ to $9.9^{\circ} \mathrm{C}$. July was the warmest month, January was the coldest ones. The average long-term air temperature in July was $+20.5^{\circ} \mathrm{C}$, in January it was minus $4.0^{\circ} \mathrm{C}$ (Table 2). The total active temperature above $5^{\circ} \mathrm{C}$ was about $3000^{\circ} \mathrm{C}$, above $10^{\circ} \mathrm{C}$ it was $2700^{\circ} \mathrm{C}$, thus testifies to sufficient heat supply of the territory.

The average annual air temperature in the Forest-Steppe exceeded the ALT $\left(8.3^{\circ} \mathrm{C}\right)$ by $1.3^{\circ} \mathrm{C}$ in $2015-16$; by $0.7^{\circ} \mathrm{C}$ in 2016-17; by $0.6^{\circ} \mathrm{C}$ in $2017-18$ (Table 2). In 2015-16, the annual rainfall was $538 \mathrm{~mm}$, or $88 \%$ of the ALT $(613 \mathrm{~mm})$, the maximum $(92 \mathrm{~mm}$ ) rainfall was observed in May when the intensity of growth processes is highly dependent on moisture and nutrients. In 2016-17, the annual amount of precipitation was $453 \mathrm{~mm}$ ( $74 \%$ of the ALT), with the maximum $(101 \mathrm{~mm})$ in the second and third decades of July. In 2017-18, this indicator was at the level of ALT, i.e. 619

\begin{tabular}{|c|c|c|c|c|c|c|c|c|c|c|c|c|c|c|}
\hline \multirow{2}{*}{ Year } & \multicolumn{12}{|c|}{ Month } & \multirow{2}{*}{\multicolumn{2}{|c|}{ Indicator }} \\
\hline & VIII & IX & $\mathbf{X}$ & XI & XII & I & II & III & IV & $\mathbf{V}$ & VI & VII & & \\
\hline \multicolumn{13}{|c|}{ Precipitation, $\mathrm{mm}$} & Sum, mm & $\%$ to ALT \\
\hline $2015-16$ & 27 & 44 & 27 & 46 & 18 & 72 & 52 & 36 & 36 & 92 & 69 & 19 & 538 & 88 \\
\hline 2016-17 & 37 & 2 & 74 & 44 & 31 & 31 & 33 & 13 & 43 & 24 & 20 & 101 & 453 & 74 \\
\hline $2017-18$ & 19 & 13 & 75 & 52 & 115 & 72 & 37 & 6 & 22 & 33 & 96 & 79 & 619 & 101 \\
\hline $\mathrm{X}$ & 62 & 58 & 39 & 42 & 41 & 34 & 30 & 35 & 42 & 55 & 91 & 84 & 613 & - \\
\hline \multicolumn{13}{|c|}{ Air temperature, ${ }^{\circ} \mathrm{C}$} & Average, ${ }^{\circ} \mathrm{C}$ & \pm to ALT \\
\hline $2016-17$ & 20.9 & 15.7 & 6.6 & 1.3 & -1.8 & -5.3 & -2.7 & 6.1 & 10.4 & 15.4 & 20.6 & 21.0 & 9.0 & 0.7 \\
\hline $2017-18$ & 22.4 & 17.0 & 8.5 & 3.4 & 2.1 & -3 & -3.7 & -7.2 & 13.2 & 18.4 & 20.2 & 15.5 & 8.9 & 0.6 \\
\hline $\mathrm{X}$ & 19.7 & 14.4 & 8.4 & 1.9 & -2.3 & -4.0 & -3.4 & 1.5 & 9.2 & 15.5 & 18.5 & 20.5 & 8.3 & - \\
\hline
\end{tabular}
$\mathrm{mm}$ with high level of precipitation in December and June.

Table 2. Precipitation and air temperature during the growing season of winter wheat in the Forest-Steppe zone.

$\mathrm{X}$ is average long-term value for $1980-2015$.

According to long-term data, the climate of the Polissia zone is moderately warm, mild, with sufficient precipitation. The average annual air temperature was $7.8-9.4^{\circ} \mathrm{C}$ (Table 3 ). January was the coldest month in the year, July was and the warmest ones with an average monthly temperature of 18.9 $21.5^{\circ} \mathrm{C}$. The absolute maximum reached $38-39^{\circ} \mathrm{C}$. In summer, west and northwest winds predominate. On average, the last frost on the ground in spring was of late April to the first decade of May, and autumn frost began in the third decade of September. The latest frost in air in spring may be in late May, and in autumn the earliest ones may be in late September. It should be noted that frosts on the soil surface in the spring end later, and in autumn occur earlier than in the air. But due to global warming, the weather conditions in the 
region have begun to change $[13,21]$.

Table 3. Precipitation and air temperature during the growing season of winter wheat in the Polissia region.

\begin{tabular}{|c|c|c|c|c|c|c|c|c|c|c|c|c|c|c|}
\hline \multirow{2}{*}{ Year } & \multicolumn{12}{|c|}{ Month } & \multirow{2}{*}{\multicolumn{2}{|c|}{ Indicator }} \\
\hline & VIII & IX & $\mathbf{X}$ & XI & XII & $\mathbf{I}$ & II & III & IV & $\mathbf{V}$ & VI & VII & & \\
\hline \multicolumn{13}{|c|}{ Precipitation, $\mathrm{mm}$} & Sum, mm & $\%$ to ALT \\
\hline 2015-16 & 2 & 27 & 26 & 69 & 42 & 48 & 53 & 35 & 65 & 145 & 39 & 34 & 585 & 116 \\
\hline 2016-17 & 55 & 9 & 135 & 44 & 59 & 40 & 28 & 29 & 17 & 25 & 44 & 68 & 553 & 110 \\
\hline 2017-18 & 53 & 40 & 102 & 49 & 113 & 44 & 38 & 7 & 2 & 23 & 101 & 145 & 717 & 143 \\
\hline $\mathrm{X}$ & 57 & 46 & 35 & 37 & 31 & 27 & 24 & 27 & 36 & 45 & 65 & 73 & 503 & - \\
\hline \multicolumn{13}{|c|}{ Air temperature, ${ }^{\circ} \mathrm{C}$} & Average, ${ }^{\circ} \mathrm{C}$ & \pm to ALT \\
\hline $2015-16$ & 20.3 & 16.9 & 5.2 & 3.7 & 1.5 & -7.2 & 1.2 & 3.3 & 11.3 & 15.0 & 19.5 & 21.5 & 9.4 & 2.1 \\
\hline 2016-17 & 19.7 & 13.9 & 6.1 & 0.3 & -2.4 & -5.8 & -3.2 & 5.2 & 9.1 & 13.8 & 18.1 & 18.9 & 7.8 & 0.5 \\
\hline 2017-18 & 20.5 & 15.0 & 7.2 & 2.7 & 0.9 & -3.4 & -4.9 & 2.2 & 11.3 & 17.7 & 19.3 & 20.4 & 9.1 & 1.8 \\
\hline $\mathrm{X}$ & 19.1 & 13.7 & 7.3 & 1.4 & -3.4 & -5.9 & -5.5 & -0.5 & 7.9 & 15.0 & 18.4 & 20.2 & 7.3 & - \\
\hline
\end{tabular}

$\mathrm{X}$ is average long-term value for $1980-2015$.

During the research period, weather conditions in the Polissia zone also varied significantly (Table 3 ). The average annual air temperature exceeded the ALT $\left(7.3^{\circ} \mathrm{C}\right)$ by $2.1^{\circ} \mathrm{C}$ in $2015-16$; by $0.5^{\circ} \mathrm{C}$ in $2016-17$; by $1.8^{\circ} \mathrm{C}$ in $2017-18$. In $2015-16$, the annual precipitation was $585 \mathrm{~mm}$, or $116 \%$ to the ALT $(503 \mathrm{~mm})$ at the maximum $(145 \mathrm{~mm})$ precipitation level in May during heading stage when simultaneously with the intensive growth of the stem due to rapid elongation of the second to last internode the head emerged from the flag leaf sheath. In 2016-17, the annual precipitation was $553 \mathrm{~mm}(110 \%$ of the ALT) with maximum (135 mm) rainfall in October. In 2017-18, this indicator was 717 $\mathrm{mm}(143 \%$ of the ALT) with high precipitation level in October, December, June, and July.

Contrasting weather conditions in the Forest-Steppe zone and the Polissia over the years of the research have confirmed climate change towards instability and more continentality.

In the experiments conducted the differentiation of initial data by the factor "Unregulated (Ecological) Environmental Conditions" was provided the study of winter wheat varieties under different vegetation conditions in some locations of the climatic zones Forest-Steppe and Polissia. Ten winter bread wheat varieties were studied as a source material: Podolianka (standard), Trudivnytsia myronivs'ka, Horlytsia myronivs'ka, MIP Valensiia, Hospodynia myronivs'ka, MIP Kniazhna, Vezha myronivs'ka, MIP Dniprianka, Estafeta myronivs'ka, Hratsiia myronivs'ka.

\subsubsection{Hydrothermal Coefficient}

In the Forest-Steppe zone, different conditions during period of active vegetation of winter wheat were observed through the years of the research (Figure 1). The growing season 2015-16 was characterized with total HTC $=1.15$ being the normal for optimal growth and development of wheat plants, although the pre-sowing period (August 2015) was arid $(\mathrm{HTC}=0.41)$, for the rest periods of the growing season the HTC was noted in the range of 1.14-1.95. During the harvest (July, 2016) there was minimum precipitation $(\mathrm{HTC}=0.06)$ which contributed to the timely harvesting the winter wheat varieties. The average grain yield for this growing season was $7.30 \mathrm{t} / \mathrm{ha}$ with exceeding the standard Podolianka by 0.89 t/ha. In 2016-17, soil-air autumn and spring-summer droughts were observed. The precipitation was very unevenly distributed, although during the period of active vegetation of winter wheat plants the HTC amounted to 1.16 . Thus, in October 2016, before the autumn vegetation dormancy onset, a significant precipitation was observed $(\mathrm{HTC}=3.79)$, and in the period of spring vegetation resumption (April, 2017) the HTC was 1.36. The rest months were very drought (HTC 0.04-0.49). In July 2017, $101 \mathrm{~mm}$ of precipitation fell, which slowed down the harvest and reduced the wheat grain quality. Under such unfavorable climatic conditions, the average yield for this growing season was $3.76 \mathrm{t} / \mathrm{ha}$ (below the standard by $0.27 \mathrm{t} / \mathrm{ha}$ ). The weather conditions in 2017-18 were arid with the total HTC for period of active vegetation 0.98 . In the pre-sowing and sowing periods the HTC was 0.27 and 0.26 , respectively. Excess rainfalls were observed in October 2017 and in late June 2018, i.e. $75 \mathrm{~mm}(\mathrm{HTC}=2.87)$ and $96 \mathrm{~mm}(\mathrm{HTC}=$ $1.53)$, respectively. Probably, such weather conditions negatively affected formation of the average yield for this growing season $(6.05 \mathrm{t} / \mathrm{ha})$ which was lower than the standard by $0.26 \mathrm{t} / \mathrm{ha}$.

In the Polissia zone, according to the years of research, various conditions for growth and development of winter wheat were also noted. In 2015-16, during the period of active vegetation of plants, the HTC was 1.03 and was not typical for the agro-climatic conditions of the zone. However, the pre-sowing period in 2015 was very dry: the HTC was 0.77 in August and 0.03 in September. Under such conditions, the seedbed was not prepared for sowing winter wheat, the soil around the seeds was too dry, which did not contribute to even emergence. But since the resumption of spring vegetation and during wheat heading occurrence HTC was 1.92 and 3.11, respectively which had a positive effect on formation of average grain yield $(8.71 \mathrm{t} / \mathrm{ha})$ for this growing season. In 2016-17, the HTC for the period of active vegetation of winter wheat plants was at the level of 1.3 due to excessive rainfall $(135 \mathrm{~mm})$ in October 2016 before the autumn vegetation dormancy onset $(\mathrm{HTC}=5.15)$. Rainfall environments for the rest months were arid (HTC 0.60-0.81). The average grain yield of winter wheat varieties for this growing season was 8.94 t/ha (exceeding the standard by $0.21 \mathrm{t} / \mathrm{ha}$ ). Weather conditions in 2017-18 with HTC for the period of active vegetation 1.31 were unfavorable for growth 
and development of winter wheat. Pre-sowing and sowing periods were characterized with HTC at the level of 0.89 and 0.21 , respectively. Excessive rainfall $(102 \mathrm{~mm})$ was observed in October 2017 before the autumn vegetation dormancy onset $(\mathrm{HTC}=4.21)$. In the critical periods of growth and development of winter wheat plants in 2018, the HTC was 0.05 in April and 0.43 in May. Such weather conditions probable had negative influence on formation of the average yield for this growing season $(5.65 \mathrm{t} / \mathrm{ha})$ which was lower than the standard by $0.42 \mathrm{t} / \mathrm{ha}$.

$\checkmark$ April $\square$ May $\square$ June (July $\boxplus$ August $\square$ September $\square$ October

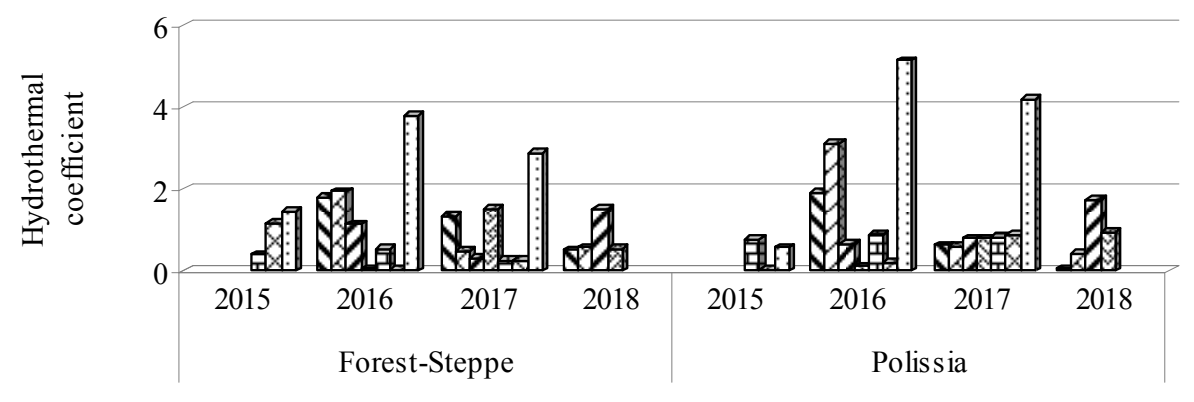

Agro-ecological zone, year

Figure 1. Characteristics of the conditions of vegetation periods of winter wheat in terms of hydrothermal regime (HTC) in the Forest-Steppe and Polissia.

From the analysis of weather conditions both by months and by whole growing seasons a significant difference in dynamics of environmental factors (the total air temperature, precipitation, the value of HTC). During the first part of growing season the vegetative, reproductive, and generative organs of plants are formed, and in the second part flowering, fertilization and formation of new seed generation take place. Therefore, the requirements for the external environment and the response to changes in the dynamics of environmental conditions are specific to each part of plant growing season.

\subsubsection{Relative Index of HTC and Relative Environmental Index}

Vegetation conditions for winter wheat according to RHTC were favorable in the agro-ecological zone of the ForestSteppe for the whole research period, in the Polissia zone in 2015-16; according to REI indicators calculated for plant height the vegetation periods were close (86-113\%) to norms for all variants of the experiment (Figure 2).

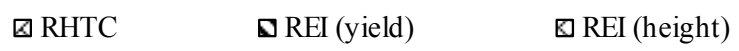

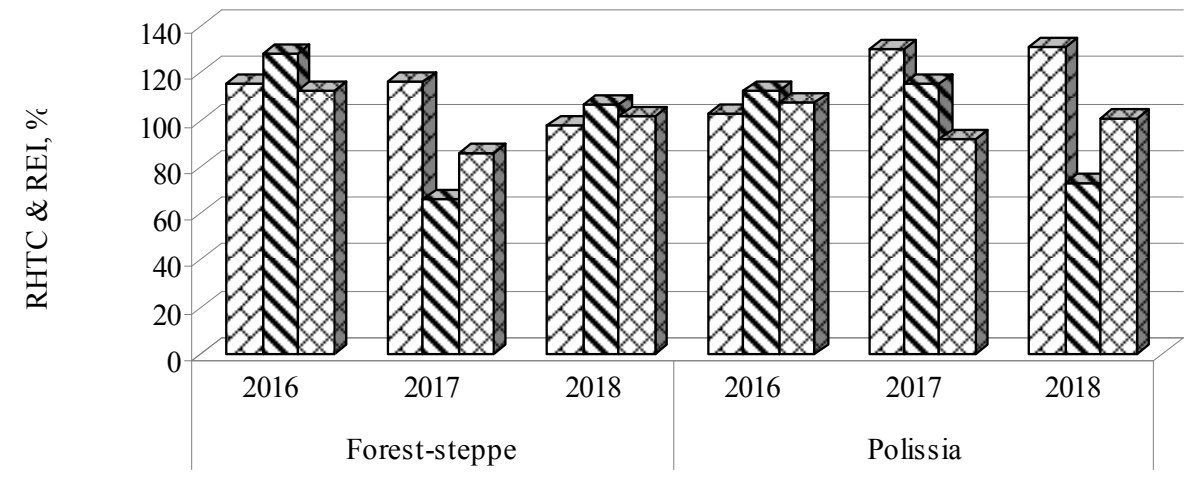

Agro-ecological zone, year

Figure 2. Variation of the components of winter wheat yield formation depending on the hydrothermal regime.

In the Forest-Steppe zone, the REI indicator calculated for yield was significantly high (128\%) in 2016 and low (66\%) in 2017. In the Polissia zone in 2018, this indicator (73\%) also was significantly low.

It should be noted that in the Forest-Steppe zone the conditions of winter wheat vegetation in 2015-16 (RHTC = $115 \%$ ) and 2016-17 (RHTC $=116 \%$ ) were close to moderately unfavorable. In 2015-16, only the pre-sowing period and the harvesting time were very dry, they did not negatively affect on winter wheat yield formation. At the other stages of growing season, the formation of vegetative mass and grain yield took place under favorable moisture conditions when the maximum REI indicators in terms of yield and plant height were 128 and $113 \%$, respectively. In 
contrast, in 2016-17 the distribution of precipitation was very uneven, arid conditions were observed in the early and later stages of the growing season when yield components were being formed that had a negative effect on winter wheat yield formation: the minimum REI were 66 and $86 \%$, respectively. Unfavorable arid conditions in 2016/2017 adequately (in the direction of a significant decrease) affected the formation of vegetative mass and harvest as a whole.

In the Polissia zone, the conditions of winter wheat vegetation in 2016-17 $($ RHTC $=130 \%)$ and 2017-18 $($ RHTC $=131 \%)$ were close to unsatisfactory. In 2017, from resuming spring vegetation (it was noted on 4 March to booting emergence the average air temperature $\left(5.2^{\circ} \mathrm{C}\right)$ was significantly higher than the average long-term value $\left(-0.5^{\circ} \mathrm{C}\right)$ with sufficient rainfall $(29$ $\mathrm{mm}, 107 \%$ to normal) which contributed to rapid regrowth and intensive growth of winter wheat plants. In 2017-18, at the later resuming spring vegetation date ( 9 April), the average air temperature in the same period was $2.2^{\circ} \mathrm{C}$, and the precipitation in March and April was significantly lower $(7 \mathrm{~mm}, 26 \%$ and 2 $\mathrm{mm}, 6 \%$, respectively), in June and July it was significantly higher (101 mm, 155\% and $145 \mathrm{~mm}, 199 \%$, respectively), which led to lodging of crops and negatively effected on yield formation as a whole.

In the Forest-Steppe zone, a tendency was observed: as the REI in terms of plant height decreased the grain yield of winter wheat decreased. Under the balanced combination of the year conditions (RHTC) and the conditions during winter wheat yield formation (REI in terms of yield, plant height), all three indicators get closer to $100 \%$. In the Polissia zone, irregular distribution of precipitation during critical periods of vegetation, i.e. drought during regrowth and booting or excess rainfall during grain filling and formation (2017-18) had a greater impact. This can be explained by the fact that within the agro-ecological zone the deviations of monthly averages from the average long-term precipitation are more significant than in the Forest-Steppe zone.

Thus, the meteorological conditions of the years of the research differed significantly in temperature and moisture conditions during both the growing season of winter wheat as a whole and some phases of development of winter wheat plants. Taking into account the peculiarities of weather conditions in the Forest-Steppe and Polissia regions of Ukraine made it possible to obtain reliable data on their relevance to winter wheat cultivation requirements and their comfort level for realization of the crop potential, as well as to identify varieties with high ecological plasticity that less respond to environmental fluctuations.

\subsection{Yield and Ecological Plasticity of Winter Bread Wheat Varieties}

Yield is complex indicator of genotype adaptation to growing conditions. From the results of this research a significant variation in yield was observed depending on the conditions of the year and the agro-ecological zone.

According to the results of ANOVA, it was found the most influence on winter wheat yield for interaction of factors "Year $\times$ Zone" 36.4\%. The influence of "Zone" and "Year" factors was reliable, but less, i.e. $28.8 \%$ and $22.9 \%$, respectively (Table 4).

Table 4. The results of ANOVA for yield of winter wheat varieties, 2016-2018.

\begin{tabular}{lllllll}
\hline Sources of variation & SS & $\boldsymbol{d f}$ & $\boldsymbol{M S}$ & $\boldsymbol{F}$ & $\boldsymbol{p}$ & \% of total SS \\
\hline Variety & 21.28 & 9 & 2.36 & 52.43 & 0.00 & 2.4 \\
Year & 203.16 & 2 & 101.58 & 2252.71 & 0.00 & 22.9 \\
Zone & 255.59 & 1 & 255.59 & 5667.93 & 0.00 & 28.8 \\
Variety $\times$ Year & 18.37 & 18 & 1.02 & 22.63 & 0.00 & 2.1 \\
Variety $\times$ Zone & 20.49 & 9 & 2.28 & 50.48 & 0.00 & 2.3 \\
Year $\times$ Zone & 323.85 & 2 & 161.92 & 3590.89 & 0.00 & 36.4 \\
Variety $\times$ Year $\times$ Zone & 37.70 & 18 & 2.09 & 46.45 & 0.00 & 4.2 \\
Error & 8.12 & 180 & 0.05 & & & 0.2 \\
\hline
\end{tabular}

Table 5. The influence of ecological environment (year) on yield (t/ha) of winter wheat varieties in the Forest-Steppe and Polissia zones.

\begin{tabular}{|c|c|c|c|c|c|c|c|c|c|}
\hline \multirow{2}{*}{ Variety, parameter } & \multicolumn{3}{|c|}{ Forest-Steppe } & \multicolumn{3}{|l|}{ Polissia } & \multicolumn{3}{|c|}{ Statistical parameters } \\
\hline & $2015-16$ & 2016-17 & 2017-18 & 2015-16 & 2016-17 & 2017-18 & Yi & $\boldsymbol{b}_{i}$ & $S^{2} d_{i}$ \\
\hline Podolianka (standard) & 6.41 & 4.03 & 6.31 & 9.97 & 8.73 & 6.07 & 6.92 & 1.00 & 0.63 \\
\hline Trudivnytsia myronivs'ka & 7.61 & 4.19 & 5.93 & 8.37 & 8.56 & 5.35 & 6.67 & 0.89 & 0.09 \\
\hline Horlytsia myronivs'ka & 8.35 & 3.68 & 5.79 & 6.63 & 8.85 & 4.58 & 6.31 & 0.89 & 1.33 \\
\hline MIP Valensiia & 7.91 & 3.91 & 6.01 & 7.33 & 9.65 & 5.78 & 6.77 & 0.93 & 0.68 \\
\hline Hospodynia myronivs'ka & 6.97 & 4.11 & 6.36 & 8.93 & 9.62 & 4.87 & 6.81 & 1.07 & 0.33 \\
\hline MIP Kniazhna & 6.59 & 3.45 & 5.11 & 8.28 & 8.17 & 5.29 & 6.15 & 0.95 & 0.07 \\
\hline Vezha myronivs'ka & 6.90 & 3.33 & 5.32 & 8.88 & 9.02 & 5.96 & 6.57 & 1.09 & 0.17 \\
\hline MIP Dniprianka & 7.15 & 3.77 & 6.59 & 9.33 & 9.42 & 6.25 & 7.09 & 1.06 & 0.12 \\
\hline Estafeta myronivs'ka & 7.81 & 3.41 & 6.28 & 9.69 & 8.06 & 6.95 & 7.03 & 0.99 & 0.83 \\
\hline Hratsiia myronivs'ka & 7.28 & 3.68 & 6.79 & 9.66 & 9.27 & 5.42 & 7.02 & 1.13 & 0.20 \\
\hline$Y j$ & 7.30 & 3.76 & 6.05 & 8.71 & 8.94 & 5.65 & 6.73 & & \\
\hline$Y x$ & 6.73 & & & & & & - & - & - \\
\hline Ij & 0.57 & -2.97 & -0.68 & 1.98 & 2.21 & -1.08 & & & \\
\hline
\end{tabular}

$Y i=$ average yield of the variety for three years; $b_{i}=$ linear regression coefficient; $S^{2} d_{i}=$ stability variance; Yj $=$ average yield for the year; Yx $=$ average yield for the entire period of the study; $\mathrm{Ij}=$ environmental index. 
The level of average yield of genotype in all environments does not fully reflect the essence of the phenomenon of adaptation, because there is inherited not level of a particular trait, but variation range of the genotype as its response to environmental influence [14]. The response of varieties in favorable years for winter wheat vegetation indicates their yield potential, but in unfavorable years does their adaptability. According to the productive potential, the following varieties there were identified: Horlytsia myronivs'ka in the Forest-Steppe zone (2015-16, $I j=0.57$ t/ha) with maximum yield of $8.35 \mathrm{t} / \mathrm{ha}$, MIP Valensiia, Hospodynia myronivs'ka, and MIP Dniprianka in the Polissia zone $(2016-17 ; I j=2.21 \mathrm{t} / \mathrm{ha})$ with maximum yield of 9.65 , 9.62 , and $9.42 \mathrm{t} / \mathrm{ha}$, respectively. It should be noted that in the Polissia zone in 2015-16 $(I j=2.21 \mathrm{t} / \mathrm{h}$ ) $)$ the varieties Estafeta myronivs'ka, Hratsiia myronivs'ka, MIP Dniprianka have formed yield that significantly exceeded the average for this variant of the experiment 9.69, 9.66, 9.33 t/ha (Table 5).

For the Forest-Steppe zone in favorable conditions the variety Horlytsia myronivs'ka realize its yield potential maximally; for the Polissia zone these are the varieties MIP Dniprianka, MIP Valensiia, Hospodynia myronivs'ka, Estafeta myronivs'ka, Hratsiia myronivs'ka. In unfavorable conditions in the Forest-Steppe zone (2015-16; $I j=-2.97$ t/ha) the adaptive varieties include Trudivnytsia myronivs'ka (with maximum yield of $4.19 \mathrm{t} / \mathrm{ha}$ ) and Hospodynia myronivs'ka (4.11 t/ha), and in the Polissia zone (2017-18; Ij $=-1.08 \mathrm{t} / \mathrm{ha})$ it is Estafeta myronivs'ka (6.95 t/ha).

The regression coefficient characterizes average response of genotype to changes in environmental conditions as well as its plasticity and makes it possible to predict trait variation within the conditions studied. According to this indicator, the varieties were divided into groups: 1) the varieties with more responsiveness on growing conditions and with higher adaptability to more favorable conditions $\left(b_{i}>1\right)$, namely MIP Dniprianka $\left(b_{i}=1.06\right)$, Hospodynia myronivs'ka $\left(b_{i}=\right.$ 1.07), Vezha myronivs'ka $\left(b_{i}=1.09\right)$, Hratsiia myronivs'ka $\left.\left(b_{i}=1.13\right) ; 2\right)$ the varieties with weak reaction $\left(b_{i}<1\right)$ and with higher adaptation to unfavorable conditions Trudivnytsia myronivs'ka and Horlytsia myronivs'ka $\left(b_{i}=\right.$ 0.89), MIP Valensiia $\left(b_{i}=0.93\right)$, MIP Kniazhna $\left(b_{i}=0.95\right)$, Estafeta myronivs'ka $\left.\left(b_{i}=0.99\right) ; 3\right)$ the varieties with optimal response to growing conditions $\left(b_{i}=1\right)$, it is Podolianka $\left(b_{i}=1.00\right)$. The varieties Horlytsia myronivs'ka, Trudivnytsia myronivs'ka, MIP Valensiia, and MIP Kniazhna were specifically adapted genotypes being able to realize high productive potential under favorable growing conditions, but gap yield under unfavourable conditions. The variety Estafeta myronivs'ka was characterized with relatively low plasticity, but with high average yield and specific adaptability to adverse conditions, i.e. it significantly reduced yield in the Forest-Steppe zone, whereas it formed the maximum yield level in the Polissia zone.

The stability variance $S^{2} d_{i}$ (standard deviation) shows how reliably the variety corresponds to the plasticity estimated by regression coefficient. The closer to zero $S^{2} d_{i}$ is, the less empirical trait values differ from the theoretical ones located on the regression line [20].

The lower is the standard deviation, the more stable yielding capacity is under different environmental conditions. The varieties MIP Kniazhna $\left(S^{2} d_{i}=0.07\right)$, Trudivnytsia myronivs'ka $\left(S^{2} d_{i}=0.09\right)$, MIP Dniprianka $\left(S^{2} d_{i}=0.12\right)$, Vezha myronivs'ka $\left(S^{2} d_{i}=0.17\right)$, Hratsiia myronivs'ka $\left(S^{2} d_{i}\right.$ $=0.20$ ) were more stable ones with lower numerical value of $S^{2} d_{i}$. The varieties Horlytsia myronivs'ka $\left(S^{2} d_{i}=1.33\right)$, Estafeta myronivs'ka $\left(S^{2} d_{i}=0.83\right)$, MIP Valensiia $\left(S^{2} d_{i}=\right.$ 0.68 ) were the most unstable ones. The most yield variation was observed in the Forest-Steppe zone because of unfavorable conditions in two growing seasons 2016-17 ( $I j=$ $-2.97 \mathrm{t} / \mathrm{ha})$ and $2017-18(I j=-0.68 \mathrm{t} / \mathrm{ha})$.

\section{Conclusions}

According to the results of analysis of variance, the influence of various factors (varieties, hydrothermal conditions, agro-ecological zones and their interaction) on yielding capacity of winter wheat was established. The presented parameters of ecological plasticity and stability made it possible characterize winter wheat varieties more detaily, taking into account cultivation in certain agro-ecological zones, which would allow to obtain high yields under certain growing conditions with properly chosen winter wheat varieties.

\section{References}

[1] Acquaah, G. (2012). Principles of Plant Genetics and Breeding. 2-nd Edition. Oxford: Wiley-Blackwell. doi: $10.1002 / 9781118313718$.

[2] Agriculture of Ukraine 2016. Statistical Bulletin (2017). Kyiv: State Statistics Service of Ukraine, 246 p. (UA).

[3] Demydov, O. A., Vasylkivskyi, S. P., \& Hudzenko, V. M. (2017). Ecological and genetic aspects of winter barley selection to increase its productive and adaptive potential in the forest-steppe of Ukraine. Agroecological Journal, 2, 194200 (UA). doi: 10.33730/2077-4893.2.2017.220293.

[4] Dockter, C., Gruszka, D., Braumann, I., Druka, A., Druka, I., Franckowiak, J., Gough, S. P., Janeczko, A., Kurowska, M., Lundqvist, J., Lundqvist, U., Marzec, M., Matyszczak, I., Muller, A. H., Oklestkova, J., Schulz, B., Zakhrabekova, S., \& Hansson, M. (2014). Induced variations in brassinosteroid genes define barley height and sturdiness, and expand the green revolution genetic toolkit. Plant Physiol., 166 (4), 19121927. doi: 10.1104/pp.114.250738.

[5] Eberhart, S. A., \& Russel, W. A. (1966). Stability parameter for comparing varieties. Crop Sci., 6 (1), 36-40.

[6] Eriksson, G., Clapham, D., \& Ekberg, I. (2006). An Introduction to Forest Genetics. 2-nd Edition. Uppsala: SLU, $185 \mathrm{p}$.

[7] Gauch, H. G., Rodrigues, P. C., Munkvold, J. D., Heffner, E. L., \& Sorrells, M. (2011). Two new strategies for detecting and understanding QTL $\times$ environment interactions. Crop Sci., 51 (1), 96-113. doi: 10.2135/cropsci2010.04.0206. 
[8] Gudzenko, V. N. (2019). Statistical and graphical (GGE biplot) evaluation of the adaptive ability and stability of winter barley breeding lines. Vavilov J. Gen. Breed., 23 (1), 110-118 (RU). doi: 10.18699/VJ19.469.

[9] Haida, Yu. I., Sishchuk, M. N., \& Yatsyk, R. M. (2013). Environmental stability and plasticity of growth traits of Quercus robur L. and Pinus sibirika Du Tour. in provenance trials. Scientific bulletin of UNFU, 23 (13), 101-109 (UA).

[10] Hill, J. (2009). Genotype-environment interaction - a challenge for plant breeding. Agricultural Sci., 85 (3), 477493. doi: $10.1017 / \mathrm{S} 0021859600062365$.

[11] Khangil'din, V. V., \& Litvineno, N. A. (1981). Homeostaticity and adaptability of winter wheat varieties. Scientific and Technical Bul. VSGI, 39, 8-14 (RU).

[12] Kochmarskyi, V. S., Zamlila, N. P., Volohdina, H. B., Humeniuk, O. V., \& Voloshchuk, S. I. (2016). Adaptability level of perspective lines of bread winter wheat in the conditions of Forest-Steppe of Ukraine. Myronivka Bulletin, 2, 98-115 (UA).

[13] Konishchuk, V. V., \& Yehorova, T. M. (2018). Agroecological zoning of Ukraine. Agroecological Journal, 4, 6-22 (UA). doi: 10.33730/2077-4893.4.2018.155744.

[14] Litun, P. P. (1980). Interaction of genotype-environment in genetic research and methods of its study. In Problems of Selection and Evaluation of Breeding Material (pp. 63-93). Kiev: Naukova dumka (UA).

[15] Malosetti, M., Ribaut, J., \& van Eeuwijk, F. (2013). The statistical analysis of multi-environment data: modeling genotype-by-environment interaction and its genetic basis. Front. Physiol., 4, Article 44, 17 p. doi: 10.3389/fphys.2013.00044.

[16] Parameters of Ecological Plasticity of Agricultural Plants, Their Calculation and Analysis: Methodical Recommendations (1984). (pp. 11-20) Novosibirsk (RU).

[17] Starychenko, V. M., Golyk, L. M., Tkachova, N. A., \& Lytus, M. V. (2014). The estimation of the adaptive abilities and stability of varieties and breeder lines in the bread wheat breeding. Plant breeding and seed production, 105, 77-84 (UA). doi: 10.30835/2413-7510.2014.42055.

[18] Scheiner, S. M. (1993). Genetics and evolution of phenotypic plasticity. Annu. Rev. Ecol. Syst., 24, 35-68. doi: 10.1146/annurev.ecolsys.24.1.35.

[19] Selyaninov, G. T. (1937). Methods of agricultural characteristics of climate. In World Agroclimatic Reference Book (pp. 4-29). Moscow: Gidrometeoizdat (RU).

[20] Tymofieiev, M. M., Bondareva, O. B., \& Viniukov, O. O. (2017). Biologization of crop production is the basis for the formation of sustainable agrobiocenoses. Grain Crops, 1 (1), 79-85 (UA).

[21] Ukrainian Hydrometeorological Center. Retrieved from https://meteo.gov.ua/ua/33466/climate/climate/

[22] Van Eeuwijk, F., Bustos-Korts, D. V., \& Malosetti, M. (2016). What should students in plant breeding know about the statistical aspects of genotype $\times$ environment interactions? Crop Sci., 56 (5), 2119-2140.

[23] Vlasenko, V. A., Kochmarskyi, V. S., Koliuchyi, V. T., Kolomiiets, L. A., Khomenko, S. O., \& Solona, V. Y. (2012). Agro-climate characteristics of the territory of creation of Myronivka wheat varieties. In Breeding Evolution of Myronivka wheats (pp. 13-22). Myronivka (UA).

[24] White, T. L., Adams, W. T., \& Neale, D. B. (2009). Forest Genetics. CABI Pub. 682 p.

[25] Yan, W., \& Hunt, L. A. (2001). Interpretation of genotype $\times$ environment interaction for winter wheat yield in Ontario. Crop Sci., 41 (1), 19-25.

[26] Zamlila N. P., Demydov O. A., Volohdina H. B., Voloshchuk S. I. \& Humeniuk O. V. (2019). Yielding capacity and adaptability of winter bread wheat breeding lines in environment of Ukrainian Forest-Steppe. Myronivka Bulletin, 9, 35-42 DOI: https://doi.org/10.31073/mvis201909-05.

[27] Zas, R., Merlo, E., \& Fernandez-Lopez, J. (2004). Genotype $\times$ environment interaction in maritime pine families in Galicia, Northwest Spain. Silvae Genetica, 53 (4). 175-182. 